\title{
Changes in protein composition of the luminal fluids along the epididymis of the tammar, Macropus eugenii
}

\author{
R. C. Jones
}

Department of Biological Sciences, The University of Newcastle, New South Wales 2308, Australia

\begin{abstract}
Summary. Micropuncture samples of luminal fluid were collected from the rete testis and along the epididymis. Quantitative analyses showed that the ductuli efferentes reabsorb about half the protein leaving the testis. Considerable protein is secreted by the caput epididymidis (initial segment) and there is a net loss of protein from the corpus and cauda epididymidis.

Denatured, polyacrylamide gel electrophoresis showed that there are 5 proteins in rete testis fluid which are not present in blood $\left(M_{\mathrm{r}}\right.$ of $14700,22800,24100,43200$ and $44800)$. One of these proteins $\left(M_{\mathrm{r}} 14700\right)$ is lost from plasma in the ductuli efferentes and $2\left(M_{r} 43200\right.$ and 44800$)$ are lost in the corpus epididymidis. Twelve proteins appear in the epididymal plasma and are not present in rete testis fluid or blood: 6 appear in the caput epididymidis $\left(M_{\mathrm{s}} 30000,31000,32300,17400,18700\right.$ and 21400$)$, 3 in the corpus epididymidis $\left(M_{\mathrm{r}} 12800,39800\right.$ and 90600$)$ and 3 in the cauda epididymidis $\left(M_{\mathrm{r}} 10900,56300\right.$ and 63000$)$. A protein with the same molecular weight as a blood protein (149500) accumulates in the corpus and cauda epididymidis.

None of the samples of luminal fluid contained particulate matter other than spermatozoa, indicating that the tammar is a useful animal for micropuncture studies.
\end{abstract}

\section{Introduction}

Orgebin-Crist \& Jahad (1979) showed that sperm maturation in the epididymis is dependent on the synthesis and secretion of protein by the epididymal epithelium. Epididymal proteins have been implicated in various aspects of sperm maturation including their association with the sperm plasma membrane (Cameo \& Blaquier, 1976; Oliphant \& Singhas, 1979; Voglmayr et al., 1982) and an increased ability of spermatozoa to bind to the zona pellucida (Saling, 1982; Orgebin-Crist \& Fournier-Delpech, 1982) and to fertilize ova (González Echeverría et al., 1984; Moore \& Hartman, 1984).

Proteins are reabsorbed (Koskimies \& Kormano, 1975; Djakiew \& Jones, 1983) and secreted by the extratesticular ducts of mammals. The occurrence of proteins which are not present in blood or rete testis fluid have been demonstrated in luminal fluids from the epididymis of all mammals which have been studied. Using one-dimensional polyacrylamide gel electrophoresis, about 6 epididymal specific proteins were identified in the rat (Jones et al., 1980; Brooks \& Higgins, 1980), 6 in the rabbit (Jones et al., 1981), 7 in the hamster (Ganzález Echeverría et al., 1982) and 7 in the ram (Jones et al., 1982). The epididymis of only one non-eutherian mammal, the echidna, has been studied (Djakiew \& Jones, 1983) and there are no reports of comparable studies on a marsupial.

This paper examines the role of the epididymis of a marsupial in regulating the protein composition of the milieu in which spermatozoa are matured and stored. Jones et al. (1984) described the structural differentiation of the epididymis of the tammar into 3 main segments, an initial, middle and terminal segment, and showed that this segmentation corresponds to the anatomical differentiation into the caput, corpus and cauda epididymidis. Jones et al. (1984) concluded that the tammar may be a suitable animal for micropuncture studies of the epididymis since it would be 
possible to collect micropuncture samples from the initial segment free of the contamination with stereocilia which is characteristic of samples from the other mammals which have been studied (Levine \& Marsh, 1971; Koskimies \& Kormano, 1975; Hinton et al., 1980; Jenkins et al., 1980; Djakiew \& Jones, 1983; Turner, 1984).

\section{Materials and Methods}

Animals. Tammars were obtained from a colony bred at 'Gungahlin', Canberra, A.C.T., from stock originally collected from Kangaroo Island, South Australia.

Collection of micropuncture samples. The preparation of glass micropipettes and the handling of samples of luminal fluid were described in an earlier report (Djakiew \& Jones, 1983). Animals were anaesthetized by an intravenous injection of 5-sec-butyl-5-ethyl-thiobarbituric acid, sodium salt (Inactin: Byk Gulden Pharmaceuticals, Konstang, West Germany), about $50 \mathrm{mg} / \mathrm{kg}$. They were supported on a metal heater and their body temperature was monitored using a rectal probe and maintained at $36^{\circ} \mathrm{C}$. The trachea, a jugular vein and femoral artery were cannulated immediately after anaesthesia. The jugular vein was infused (Model 341 A syringe pump; Sage Instruments, Cambridge, MA, U.S.A.) with heparinized saline $(9 \mathrm{~g} \mathrm{NaCl} / 1,0.24 \% \mathrm{w} / \mathrm{v}$ heparin) at a rate of $8 \mathrm{ml} / \mathrm{h}$ and haematocrits were prepared at about hourly intervals to monitor blood volume. The cannula in the femoral artery was connected to a mercury U-tube manometer to monitor blood pressure. For the first 5 animals which were studied the mean \pm s.e.m. haematocrit and blood pressure were initially $45 \cdot 0 \pm 2.9 \%$ and $123.6 \pm 4.4 \mathrm{mmHg}$ respectively, and remained fairly constant during the experimental period. The values were much the same in the remaining animals.

The left testis and epididymis were freed from the scrotum and prepared for micropuncture by supporting them in a Perspex cup heated to $32^{\circ} \mathrm{C}$ by water circulating through channels in the base of the cup. The exposed organs were covered with water-saturated paraffin oil and the oil was continuously dripped onto the micropuncture site.

Micropuncture samples were collected from the rete testis, proximal and distal caput, distal corpus and middle and distal cauda epididymidis. The sample sites in the epididymis correspond to regions $1,8,18,20$ and 22 in Fig. 1a, b of Jones et al. (1984).

The micropuncture and blood samples were centrifuged in constant-bore tubing for $15 \mathrm{~min}$ at $12000 \mathrm{~g}$ in a microhaematocrit centrifuge (Hawksley, Lancing, U.K.) to separate cells from plasma. The percentage volumes of sperm and erythrocytes were estimated as the ratio of length of tubing occupied by the cells: total length occupied by the sample. The concentrations of spermatozoa in samples of rete testis fluid and caudal epididymal fluid were also counted with a haemocytometer (6 animals).

The volume of the sample was measured by loading it into a $1 \mu$ l Microcap (Drummond Scientific Co., Broomall, PA, U.S.A.) and measuirng its length with a stage micrometer under a dissecting microscope. The fluid was then dispensed into $20 \mu \mathrm{l} 2.9 \%(\mathrm{w} / \mathrm{v})$ sodium citrate containing $0.5 \%(\mathrm{v} / \mathrm{v})$ Triton-X100, mixed with a vortex mixer and loaded into a haemocytometer.

Analysis of proteins. Protein determinations and electrophoreses were carried out as described by Djakiew \& Jones (1983). Gels of samples from blood and fluid from the rete testis and cauda epididymidis were loaded with $10 \mu \mathrm{g}$ protein per well and stained with Coomassie Brilliant blue R250 (Sigma, St Louis, MO, U.S.A). Gels of blood and all the micropuncture sites were loaded with $0.5 \mu \mathrm{g}$ protein per well and stained with silver reagent (Merril $e t$ al., 1981). Gels stained with Coomassie blue were scanned with a densitometer (R \& D Quick Scan densitometer: Helena Laboratories, Beaumont, TX, U.S.A.) and gels stained with silver reagent were photographed. Estimates of apparent molecular weight $\left(M_{\mathrm{r}}\right)$ were determined using molecular weight calibration proteins (Pharmacia, Uppsala, Sweden) as standards in graphs of relative mobility of protein versus $\log$ of molecular weight.

Analysis of data. Three gels were prepared per sample site per animal for each of the stains. The mean molecular weights for these 3 gels were used to calculate the variance between animals which was used to determine the standard errors shown in the 'Results'.

\section{Results}

All of the micropuncture samples were free from contamination with cellular material other than sperm. Mean estimates of spermatocrits and fluid absorption are shown in Table 1 . The mean \pm s.e.m. concentration of spermatozoa in rete testis fluid was $59 \cdot 3 \pm 12 \cdot 1 \times 10^{3} / \mathrm{ml}$. Spermatocrits show that the ductuli efferentes reabsorb most of the fluid leaving the testis. The caput epididymidis reabsorbs most of the remaining fluid ( $10 \%$ of the fluid leaving the testis), and the corpus epididymidis reabsorbs about a quarter of the fluid that enters it. At the distal end of the cauda epididymidis the concentration of spermatozoa was $6793 \pm 486 \times 10^{3} / \mathrm{ml}$.

Quantitative determinations of protein (Table 1) showed that its concentration in rete testis fluid is about $1 \%$ of the concentration in blood. In the ductuli efferentes there is a net loss of about 
Table 1. Concentration of protein in blood and concentration of spermatozoa and proteins in luminal fluids collected by micropuncture from the rete testis and epididymis

\begin{tabular}{|c|c|c|c|}
\hline Sample site $\dagger$ & $\begin{array}{c}\text { Spermatocrits } \\
(\%) \ddagger\end{array}$ & $\begin{array}{l}\text { Absorption of } \\
\text { fluid }(\%) \S\end{array}$ & $\begin{array}{c}\text { Protein } \\
\text { conc. }(\mathrm{mg} / \mathrm{ml}) \uparrow\end{array}$ \\
\hline $\begin{array}{l}\text { Rete testis } \\
\text { Epididymis }\end{array}$ & $1 \cdot 5 \pm 0.2$ & - & $0 \cdot 9 \pm 0 \cdot 4$ \\
\hline $\begin{array}{l}\text { Epididymis } \\
\text { Proximal caput (1) }\end{array}$ & $11 \cdot 3 \pm 2 \cdot 5^{* * *}$ & 87 & $3 \cdot 0 \pm 0 \cdot 5^{L * * *}$ \\
\hline Distal caput ( 8 ) & $50 \cdot 8 \pm 3 \cdot 4^{* * *}$ & 78 & $43 \cdot 4 \pm 7 \cdot 7^{\mathrm{G} * * *}$ \\
\hline Distal corpus (18) & $69.9 \pm 4.5^{* *}$ & 27 & $32 \cdot 2 \pm 7 \cdot 0^{\mathrm{L} *}$ \\
\hline Middle cauda (20) & $66.9 \pm 1.6$ & 0 & $18 \cdot 2 \pm 2 \cdot 3^{\mathrm{L} * *}$ \\
\hline Distal cauda (22) & $61 \cdot 3 \pm 2 \cdot 6$ & -9 & $15 \cdot 6 \pm 2 \cdot 2$ \\
\hline Blood & - & - & $71.6 \pm 3.7$ \\
\hline
\end{tabular}

Values are mean \pm s.e.m. from 6 animals.

$\dagger$ Numbers in parentheses correspond to regions shown in Fig. 1 of Jones et al. (1984).

¥Asterisks indicate that value is statistically different from mean for nearest proximal site: ${ }^{* *} P<0.01$ and $* * * P<0.001$.

§xpressed as the percentage absorbed between the site under consideration and the site proximal to it.

- A net loss (L) or gain (G) of protein from the luminal plasma between the site indicated and the site proximal to it is indicated; ${ }^{*} P<0.05,{ }^{* *} P<0.01$ and ${ }^{* * *} P<0.001$.

half the protein leaving the testis, there is a considerable increase in protein concentration in the caput epididymidis and there is a net loss of protein from the luminal plasma in the corpus and cauda epididymidis.

Figs 1 and 2 show tracings of a Coomassie blue-stained gel and a photograph of a silver-stained gel, respectively. Comparison of these gels shows that the resolution was greatest in the gels stained with silver, but the pale bands corresponding to molecular weights of 30000,31300 and 32300 in the cauda epididymidis indicate that some of the silver staining may not be quantitative. It was interpreted that rete testis fluid formed 5 bands which were not present in blood (corresponding to $M_{\mathrm{r}}$ values of $14700,22800,24100,43200$ and 44800 ). Some of the proteins were removed from the plasma or modified during passage through the sperm ducts: this occurred in the ductuli efferentes for 1 band $\left(M_{\mathrm{r}} 14700\right)$ and the corpus epididymidis for 2 other bands $\left(M_{\mathrm{r}} 43200\right.$ and $44800)$.

Twelve bands were present in gels of epididymal fluids which were not present in samples from blood or rete testis fluid. It was interpreted that 6 of these proteins appeared in the caput epididymidis $\left(M_{\mathrm{r}} 30000,31300,32300,17400,18700\right.$ and 21400$), 3$ in the corpus epididymidis $\left(M_{\mathrm{r}}\right.$ $12800,39800$ and 90600$)$ and 3 in the cauda epididymidis $\left(M_{r} 10900,56300\right.$ and 63000$)$. The band corresponding to a protein of $M_{\mathrm{r}} 10900$ was present in at least 2 gels per animal in the gels stained with Coomassie blue but was only a weak band (in at least one gel/animal) in the gels stained with silver reagent. One protein which corresponded to a blood protein $\left(M_{\mathrm{r}} 149500\right)$ formed a band in samples from the distal part of the corpus epididymidis and a very dark band in samples from the cauda epididymidis.

\section{Discussion}

Technical problems of obtaining uncontaminated samples of luminal fluids from the initial segments of the ductus epididymidis of the rat (Zones 1 and 2; Reid \& Cleland, 1957; Fawcett \& Hoffer, 1979) have meant that micropuncture samples of luminal fluid have not been collected between the rete testis and regions of the ductus epididymidis distal to the initial segments (see 


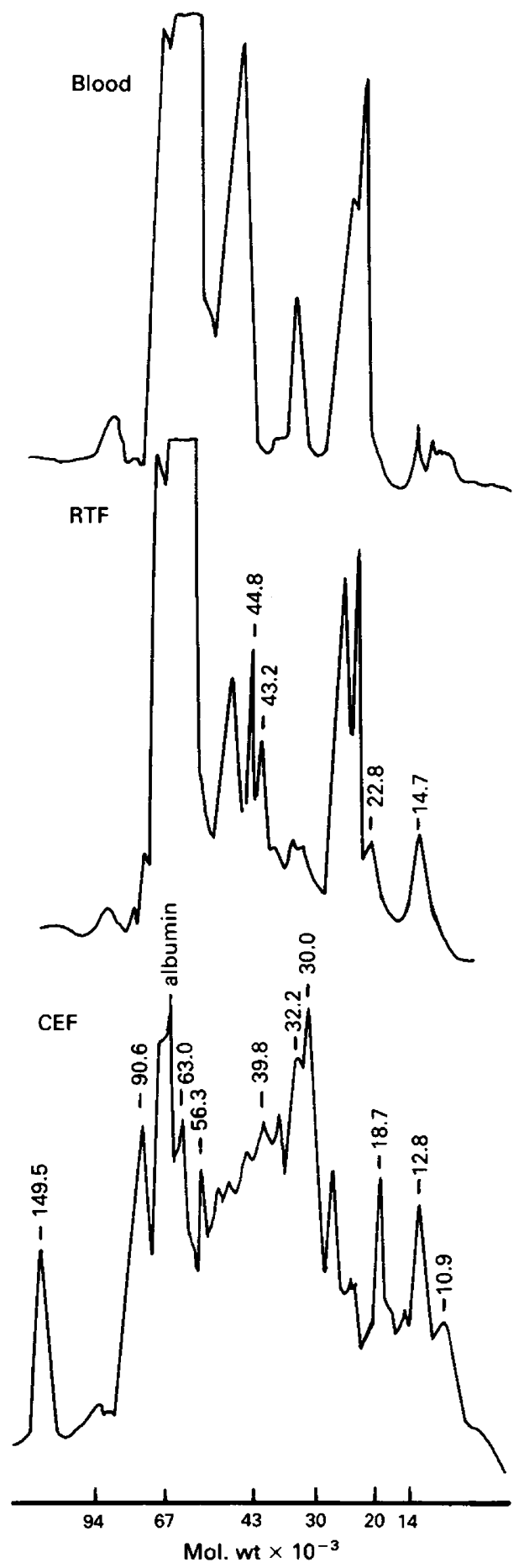

Fig. 1. Densitometer tracings of denatured linear gradient polyacrylamide gels of blood plasma and micropuncture samples from the rete testis (RTF) and cauda epididymidis (CEF) of tammars. Gels were loaded with $10 \mathrm{~g}$ protein and stained with Coomassie blue. 


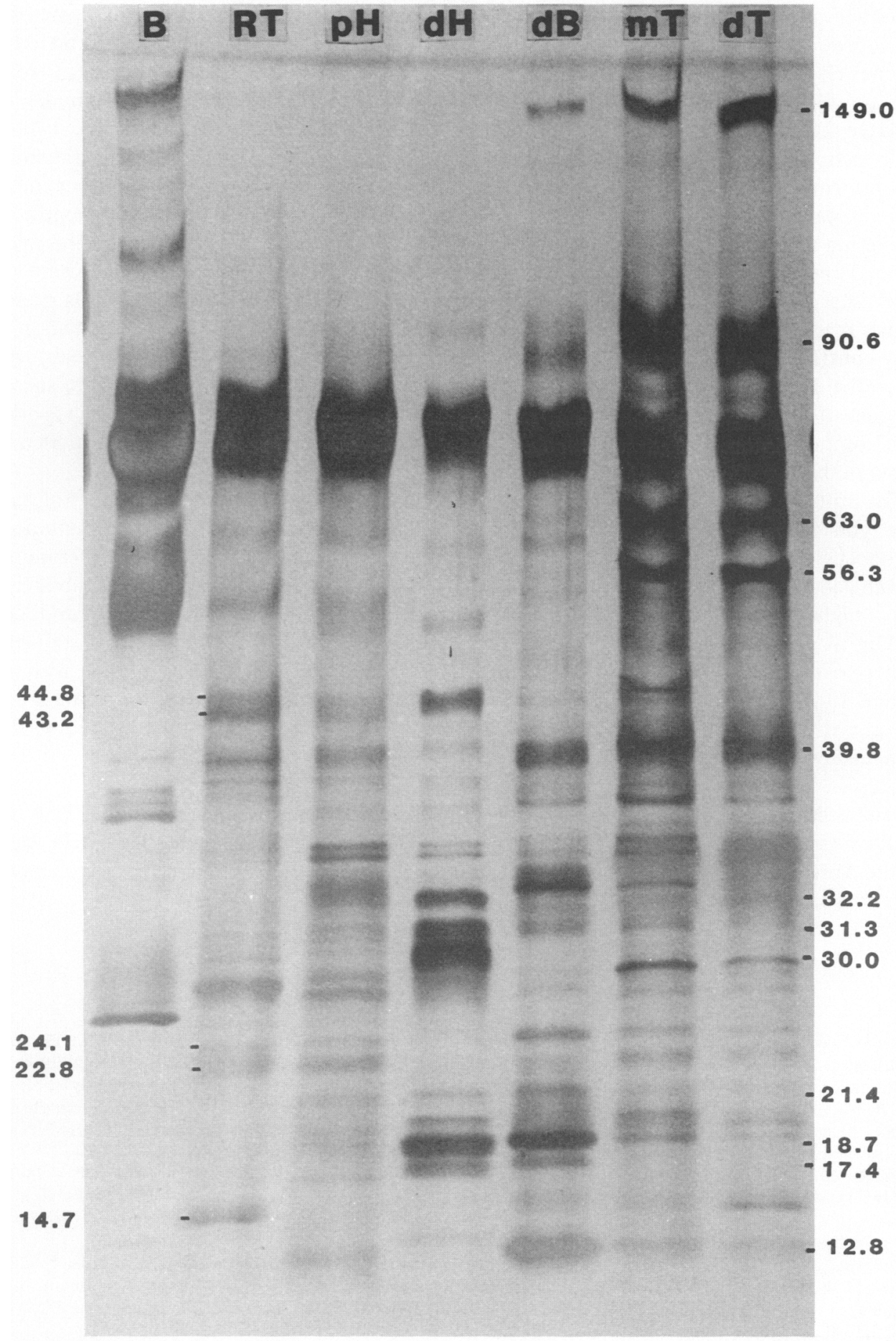

Fig. 2. Photograph of denatured linear-gradient polyacrylamide gel of blood plasma (B) and micropuncture samples of the rete testis (RT) and epididymis of the tammar. $\mathrm{pH}$, proximal caput; $\mathrm{dH}$ distal caput; $\mathrm{dB}$, distal corpus; $\mathrm{mT}$, middle cauda; $\mathrm{dT}$, distal cauda. Gels were loaded with $0.5 \mu \mathrm{g}$ protein. Silver stain. Numerical values are $M_{\mathrm{r}} \times 10^{-3}$. 
'Introduction'). Consequently, the functions of the ductuli efferentes and the initial segments have been confounded leading to misinterpretation of data. Therefore, this is the first report on a therian mammal clarifying the reabsorptive role of the ductuli efferentes and distinguishing it from the secretory role of the initial segment. The initial segment of the tammar (caput epididymidis) seems to secrete most of the protein secreted by the epididymis.

Collection and analysis of micropuncture samples of luminal fluids from the epididymis provides information on quantitative changes in protein which are not provided by other methods. However, caution is required in interpreting some of the electrophoretic data. For example, when considering the apparent reabsorption of proteins with $M_{\mathrm{r}}$ values of 24100 and 22800 between the proximal and distal ends of the caput epididymidis, it should be remembered that gels were loaded with $0.5 \mu \mathrm{g}$ protein from each sample. Since 3 times the concentration of protein was present in samples from the distal compared to the proximal end of the caput epididymidis, the two proteins under consideration would be diluted 3-fold at the distal end even if there was no reabsorption. Also, when bands corresponding to the same molecular weight occur in samples from successive segments of the epididymis (such as those with $M_{\mathrm{r}} 30000,31300$ and 32300), microperfusion studies of the second segment are necessary to confirm whether new protein is actually added to the plasma in the second segment.

The proteins accumulated in the epididymis of the tammar are within the same range of molecular weights as the epididymal proteins secreted by other mammals which have been studied (see 'Introduction'). The larger number of proteins identified in the tammar than in the other mammals is not considered to be significant. A reason for this proposal is because gels stained with silver reagent were of higher resolution than gels stained with Coomassie blue so that, for example, bands corresponding to proteins of $M_{\mathrm{r}} 30000$ to 32300 were only identified as 2 bands in gels stained with Coomassie blue. Also, we identified proteins in lightly staining bands such as those with an $M_{\mathrm{r}}$ value of 10900 and 21400 . Furthermore, these studies have determined only the number of proteins appearing in epididymal plasma which are not in blood or rete testis fluid and so do not distinguish whether they originate from the duct mucosa or from spermatozoa.

I thank Mrs K. Worrard, University of Newcastle, for excellent technical help; Dr L. A. Hinds and Dr C. H. Tyndale-Biscoe, CSIRO, Division of Wildlife and Rangelands Research, for help; and the Australian Research Grants Scheme and the Senate Research Committee of the University of Newcastle for financial support.

\section{References}

Brooks, D.E. \& Higgins, S.J. (1980) Characterization and androgen-dependence of proteins associated with luminal fluid and spermatozoa in the rat epididymis. J. Reprod. Fert. 59, 363-375.

Cameo, M.S. \& Blaquier, J.A. (1976) Androgencontrolled specific proteins in rat epididymis. $J$. Endocr. 69, 47-55.

Djakiew, D. \& Jones, R.C. (1983) Sperm maturation, fluid transport, and secretion and absorption of protein in the epididymis of the echidna, Tachyglossus aculeatus. J. Reprod. Fert. 68, 445-456.

Fawcett, D.W. \& Hoffer, A. (1979) Failure of exogenous androgen to prevent regression of the initial segments of the rat epididymis after efferent duct ligation or orchidectomy. Biol. Reprod. 20, 162-181.

González Echeverría, F., Cuasnicú, P.S. \& Blaquier, J.A. (1982) Identification of androgen-dependent glycoproteins in the hamster epididymis and their association with spermatozoa. J. Reprod. Fert. 64, 1-7.
González Echeverría, F., Cuasnicú, P.S., Piazza, A., Piñeiro, L. \& Blaquier, J.A. (1984) Addition of an androgen-free epididymal protein extract increases the ability of immature hamster spermatozoa to fertilize in vivo and in vitro. J. Reprod. Fert. 71, 433-437.

Hinton, B.T., White, R.W. \& Setchell, B.P. (1980) Concentrations of myo-inositol in the luminal fluid of the mammalian testis and epididymis. J. Reprod. Fert. 58, 395-399.

Jenkins, A.D., Lechene, C.P. \& Howards, S.S. (1980) Concentrations of seven elements in the intraluminal fluids of the seminiferous tubules, rete testis and epididymis. Biol. Reprod. 23, 981-987.

Jones, R., Brown, C.R., Von Glos, K.I. \& Parker, M.C. (1980) Hormonal regulation of protein synthesis in the rat epididymis. Biochem. J. 188, 667-676.

Jones, R., Von Glos, K.I. \& Brown, C.R. (1981) Characterization of hormonally regulated secretory proteins 
from the caput epididymidis of the rabbit. Biochem. J. 196, 105-114.

Jones, R., Fournier-Delpech, S. \& Willadsen, S.A. (1982) Identification of androgen-dependent proteins synthesized in vitro by the ram epididymis. Reprod. Nutr. Dével. 22, 495-504.

Jones, R.C., Hinds, L.A. \& Tyndale-Biscoe, C.H. (1984) Ultrastucture of the epididymis of the tammar, Macropus eugenii, and its relationship to sperm maturation. Cell Tiss. Res. 237, 525-535.

Koskimies, A.I. \& Kormano, M. (1975) Proteins in fluids from different segments of the rat epididymis. $J$. Reprod. Fert. 43, 345-348.

Levine, N. \& Marsh, D.J. (1971) Micropuncture studies of the electrochemical aspects of fluid and electrolyte transport in individual seminiferous tubules, the epididymis and the vas deferens in rats. $J$. Physiol., Lond. 213, 557-570.

Merril, C.R., Goldman, D., Sedman, S.A. \& Ebert, M.H. (1981) Ultrasensitive stain for proteins in polyacrylamide gel shows regional variation in cerebrospinal fluid proteins. Science, N.Y. 211, 1437-1438.

Moore, H.D.M. \& Hartman, T.D. (1984) Localization by monoclonal antibodies of various surface antigens of hamster spermatozoa and the effect of antibody on fertilization in vitro. J. Reprod. Fert. 70, 175-183.
Oliphant, G. \& Singhas, C.A. (1979) Iodination of rabbit sperm plasma membrane: relationship of specific surface proteins to epididymal function and sperm capacitation. Biol. Reprod. 21, 937-944.

Orgebin-Crist, M-C. \& Fournier-Delpech, S. (1982) Sperm-egg interaction. Evidence for maturational changes during epididymal transit. $J$. Androl. 3, $429-433$.

Orgebin-Crist, M-C. \& Jahad, N. (1979) Maturation of rabbit epididymal spermatozoa in organ culture: stimulation by epididymal cytoplasmic factors. Biol. Reprod. 21, 511-515.

Reid, B.L. \& Cleland, K.W. (1957). The structure and function of the epididymis. I. The histology of the rat epididymis. Aust. J. Zool. 5, 223-246.

Saling, P.M. (1982) Development of the ability to bind to zonae pellucidae during epididymal maturation: reversible immobilization of mouse spermatozoa by lanthanum. Biol. Reprod. 26, 429-436.

Turner, T.T. (1984) Resorption versus secretion in the rat epididymis. J. Reprod. Fert. 72, 509-514.

Voglmayr, J.K., Fairbanks, G., Vespa, D.B. \& Colella, J.R. (1982) Studies on mechanisms of surface modifications in ram spermatozoa during the final stages of differentiation. Biol. Reprod. 26, 483-500.

Received 19 August 1986 